\title{
Attitudes of Pre-service Music Teachers Studying in Undergraduate Programs in Turkey Towards Piano Courses
}

\author{
Bülent Halvaşi \\ Correspondence: Bülent Halvaşi, Marmara University, Atatürk Faculty of Education Department of Fine Arts Music \\ Education Program, İstanbul, Turkey.
}

Received: December 10, 2018

Accepted: January 3, 2019 Online Published: January 9, 2019

doi:10.11114/jets.v7i2.3844

URL: https://doi.org/10.11114/jets.v7i2.3844

\begin{abstract}
Attitude, which is one of the important topics of social psychology, is defined in the literature as a psychological element that can direct the behavior of individuals (Özmenteş and Özmenteş, 2009). According to Tolan, the attitude "in its broadest sense is the way in which the individual is standing up against the objects or subjects that contain a psychological value" (Gömleksiz, 2003). It has been proved by many research findings that attitudes developed as a natural result of interaction, greatly affect the success of the individual (Canakay, 2006). The effects starting from childhood, the experiences gained in later years and the fields related to the interests, desires and aims of the personality play the most decisive and effective role in the formation of attitudes. These features, which are valid in music education, are also very important in the piano education of the student. From all these definitions, it can be concluded that students' attitudes to the piano have important effects on their education and their use of the piano in the future (Bakığlu, 2012).

The main purpose of this research is to reveal the attitudes of pre-service teachers who take Piano courses in Music Education Departments of Faculty of Education. In this study, whether the scores obtained from the Piano lesson attitude scale showed significant difference according to some variables is also examined. The research was conducted on the students of Marmara University, Ataturk Faculty of Education, Music Education Department $(\mathrm{N}=30)$ in 2017-2018 academic year. The data of the study was collected by using the "Personal Information Form" prepared by the researcher and "Piano Lesson Attitude Scale" which was prepared to learn the pre-service teachers' thoughts about Piano Lesson. As a result of the study, it was found that there were statistically significant differences between the attitude levels of students and some variables $(\mathrm{p}<.05)$.
\end{abstract}

Keywords: piano education, piano lesson, music teacher candidates, attitude

\section{Introduction}

Attitude is a way of thinking in which the individual perceives an icon, an object, a person, or the world in terms of good or bad, useful or harmful, depending on the system of values it owns. In other words, attitude is an individual's tendency to evaluate a symbol, an object or an event in a positive or negative way (İnceoğlu, 1993: 13).

Attitudes cannot be observed directly; however, one can get an idea of the attitude of an individual by looking at his / her behavior. In spite of the inability to observe, attitudes significantly affect an individual's love, hatred and behavior (Morgan, 1991: 363). Information on attitude can be collected in various ways. One of them is the collection of direct information. Grading scales are included in this group. Propositions about the object are prepared, and the individual is asked to what extent he participated in these propositions (Ülgen, 1995: 107) and by evaluating the answers, it is determined whether the individual has a positive or negative attitude in the relevant area.

It is known that attitudes in music education can directly affect the process. Therefore, the existence, role and necessity of attitudes in achieving success in music education cannot be ignored. Attitudes should be considered among the elements that provide success or failure in all aspects of music education. Attitudes are sometimes taken as a dependent and sometimes independent variable in music education, and are studied together with different variables and are examined in relation to variables such as musical development and success (Özmenteş and Özmenteş, 2009). Another factor that affects the power of attitude is the relationship of the person to the attitude object. Being directly related to the object of attitude causes the attitude (positive or negative) related to that object to be strengthened (Güdek, 2007). 
The Piano is considered to be the most suitable instrument for music education in schools and it is an important part of musical instrument education. Targeted success in piano education is directly and indirectly related to many factors. In this context, it is known that factors such as attitude, self-efficacy, motivation and anxiety affect students' wishes and interests, performances, and thus academic success (Gün and Köse, 2013). The attitudes of individuals in piano education, which is a process based on study and individual performance, will affect the willingness to play the piano and, particularly, to study. Feelings loving or disliking the piano, being adapted to it or not, affect the success in the piano education as in many other jobs. An individual's feeling obliged to do something he doesn't like or interrogating himself about why he had to play the piano will not only affect his performance on the instrument but also his decision about having the piano education or not (Bakioğlu,2015).

It is also considered to be the most universal and the most basic instrument in terms of playing music, obtaining listening and reading skills in music, understanding music, creating musical knowledge and creating the basis for other music studies by the music educators. Therefore, piano education is an indispensable part of music programs (cited in the Kasap, 2004). Playing the piano is a complex activity in which cognitive, temporal and affective processes are employed and requires a high level of skill. Piano education is the most important factor in acquiring this skill (Gasimova, 2010).

In Piano education, learning the piano terminology and understanding the techniques needed to play are related to the cognitive domain; loving the instrument, having a disciplined attitude towards playing the piano and playing the piano in daily life are related to the affective domain; ensuring the coordination of two hands, gaining behaviours to solve problems encountered in playing the piano are related to psychomotor domain (Özen, 2004).

Learning to play the piano involves senses such as seeing, hearing, touching with the mind and body. Piano teaching should enable the student to learn music in a certain order by showing improvement in knowledge and skills such as note reading, rhythm, study technique, musical sensitivity, style knowledge (Ercan, 2008).

Numerous studies in general education have concluded that parental involvement improves student achievement. Research in music education indicates that parental involvement is beneficial to progress on a musical instrument. However, few music teachers are known to actively encourage it (Macmillan, 2004).

Training pre-service music teachers in piano, is a measure that has been adopted by all music teacher training institutions in Turkey. Piano education is offered to all pre-service music teachers in all institutions that train music teachers. By piano education, music teachers not only gain the knowledge of music necessary for their education but also the skill needed in schools for teaching music from kindergarten to high school (Kasap, 2004).

At the end of the piano education period, it is expected that the pre-service music teachers will be able to gain the basic behaviours and techniques of playing the piano as well as to be able to use the piano skills they gained in their professional life (Otacioğlu, 2005).

The piano has a significant advantage in the education and professional life of a music teacher. In the music teacher education, when the piano's usage characteristics and the appropriate education are planned and programmed in the field, it will contribute to the general music education (Kivrak, 2003). According to Kivrak (2003), when developing piano education programs in music teaching, it is important; 1 . to consider the age of starting the instrument, 2 . to set the goals based on the main target, 3. to provide the students with the ability to respond to in-field expectations, 4 . to be simultaneous with the programs of other related courses within the field, 5. To adopt the transfer of the piano lessons to the field courses and the field courses to the piano lessons, 6 . To be able to hold the accompaniment of educational repertoire in his / her own repertoire, 7. to create the ability of teaching with high use of business plan, 8. to define goals, principles, methods and approaches that inspire, question, renew and modify itself according to the requirements of the day and carry more functionality.

In the piano education, individuals' viewpoint towards playing the piano and studying is one of the factors that affect the level of success. Individuals' unwillingness to train and to play the piano or their negative attitude is an important obstacle to success. This gained negative attitude can cause the student to perceive the piano as a necessity and may have a negative effect on his / her performance. It can be said that this situation will adversely affect the efficiency of the study. Increasing the motivation level of the students by supporting the education process with positive attitudes will also affect their success (Bakıoğlu. 2012)

Undoubtedly, the skills, competencies and attitudes of pre-service music teachers regarding the use of the piano are directly related to the level of readiness at the entrance to the music education department, motivation, the piano playing conditions, time devoted to the piano study, tutors, the piano lesson objectives, materials used in the piano lessons, solidarity between lessons in the field of music and frequent usage of the gained skills in the piano (Özen, 1998: 32). In the piano education process, using the attitude scale towards the piano lesson, we can evaluate whether the programs 
show the desired success or not, and whether the attitudes are improved as well as the knowledge and skills expected of the students.

Determining the attitudes of the music teacher candidates towards the piano lesson is very important in terms of determining whether the piano education program shows the desired success and it also helps increasing the students' success in the piano lesson (Tufan and Güdek, 2008: 81).

\section{Purposes of the Research}

In line with this information, considering the attitudes of the music teacher candidates towards the Piano course, they will contribute to the fulfilment of the applied course in an efficient and objective manner and the answers to the questions listed below are sought for the purposes of the research:

1. Attitudes scores of students in Music Education Department in line with;
(a) Gender,
(b) Age,
(c) Individual instrument,
(d) Academic achievement perception,

\section{Method}

This research is a descriptive study conducted in order to determine the attitude levels of pre-service teachers who have taken piano lessons in Marmara University, Ataturk Faculty of Education, Music Education Department. The data of the study was collected in 2018.

\subsection{Research Group}

The study group of this study consisted of 30 pre-service music teachers studying at Marmara University Music Education Department in 2017-2018 academic year. The group which is selected by random sampling is consisted of senior students most of whom are women between the ages of 20-22 and 23+.

\subsection{Data Collection Tools}

Personal Information Form: It was prepared by the researcher to gather information about demographic characteristics. In this form, a total of 10 questions were prepared in order to collect information about the personal characteristics of the music teacher candidates participating in the research. In the study, selected questions were used in accordance with the objectives.

\subsection{Attitude Scale}

In order to determine the level of attitude of the student towards the piano lesson, a scale which was adopted from the scale developed by Emir (2001)for the social studies course is used.

The Cronbach Alpha reliability coefficient of the scale was calculated as .82, which consisted of items with factor load of more than .30 based on factor loadings. Accordingly, Piano Attitude Scale consists of 28 items.

\subsection{Collection of Data}

"The Personal Information Form" and "Piano Course Attitude Scale" used in the research were applied to $304^{\text {th }}$ grade students at Marmara University Atatürk Education Faculty Music Education Department.

\subsection{Analysis of Data}

Research data were collected in several stages. Firstly, the relational analyses were conducted according to the objectives of the research. The statistical analysis of the data was tested with SPSS package program in computer environment (significance was tested as .05 and .01). Then, it was determined whether the general scores of the students on the attitude scale were showing significant difference according to some variables. And non-parametric techniques (Kruskal Wallis-H and M. W. U) were used for the groups that did not show normal distribution within the groups.

\section{Results}

Findings related to the sub-problem: In the light of the answers to the following questions, the findings and results related to the 1st sub-problem of the research are explained below:

Does the Piano lesson "attitude scores" of the final year students of Music Education Department differ according to their; (a) Gender, (b) Age, (c) Individual instrument, (d) academic achievement perception? 
Table 1. Results of Mann W. U Test conducted to determine whether the Piano Attitude Scale scores of students differ in terms of Gender and Age variables $(\mathrm{N}=30)$

\begin{tabular}{lcccc}
\hline Gender & $\mathrm{n}$ & $\overline{\mathrm{x}}$ & ss & $\mathrm{P}$ \\
\hline Female & 23 & 2.119 & .286 & .265 \\
Male & 7 & 2.225 & .147 & $\mathrm{P}$ \\
\hline Age & $\mathrm{n}$ & $\overline{\mathrm{x}}$ & ss & .173 \\
\hline $20-22$ & 19 & 2.130 & .285 & .267 \\
\hline
\end{tabular}

In Table 1 the values of the students according to their gender and age are examined; There was no statistically significant difference $(p>.05)$. As a result, the gender and age of the students do not have an effect on their attitudes towards the course.

Table 2. Kruskal Wallis-H Results to determine if students' Piano Attitude Scale scores differ according to various variables $(\mathrm{N}=30)$

\begin{tabular}{lcccc}
\hline Individual Instrument & $\mathrm{n}$ & $\overline{\mathrm{x}}$ & ss & $\mathrm{P}$ \\
\hline Strings & 14 & 2.142 & .352 & \\
Brass & 11 & 2.213 & .274 & .364 \\
Others & 5 & 2.358 & .213 & \\
\hline Academic Achievement perception & $\mathrm{n}$ & $\overline{\mathrm{x}}$ & $\mathrm{ss}$ & $\mathrm{P}$ \\
\hline Successful & 14 & 2.642 & .354 & \\
Intermediate level successful & 10 & 2.255 & .196 & .030 \\
Unsuccessful & 6 & 2.432 & .245 &
\end{tabular}

In Table 2, a non-parametric technique, Kruskal Wallis $\mathrm{H}$ analysis, was used to determine which groups had significant differences. As a result of the analysis conducted in order to determine whether the attitude scale scores of the students participating in the study showed a significant difference according to the various variables; While there was no statistically significant difference in terms of "individual instrument" status ( $>.05)$, there was a significant difference between the group means according to the "academic achievement perception" variable $(p<.05)$. After this process, Mann Whitney U test which was preferred in paired comparisons to determine which groups had significant differences after Kruskal Wallis was used. As a result of the analyzes, it was determined that in the case of the academic achievement perception of the participants, the difference between the groups that marked the successful and intermediate level of success, the difference occurred in favour of the group of students who marked successful.

\section{Conclusion, Discussion and Suggestions}

In his study Küpana (2011) examined the students in the experimental group who had piano lessons with a programme including deciphered system based on the systematic education, and the students in the control group who took piano lessons based on the existing normal education. In this study, it was determined that there was a significant difference between the post-test piano lesson attitude scale scores .001 level in favour of the experimental group. According to this result, it is observed that the piano teaching program provides positive differences in the attitudes of the students towards the piano lesson. The current research supports this issue. In this study, it was tried to determine the attitudes of pre-service music teachers towards Piano lesson.

In the research, when the attitudes of the music pre-service music teachers according to their gender and ages are examined no statistically significant difference was found. As a result, it is seen that the gender and age of the students do not have an effect on their attitudes towards the course.

As a result of the analysis conducted in order to determine whether the attitude scale scores of the students participating in the study showed a significant difference according to the various variables, no statistically significant difference in terms of "individual instrument status" was detected, but according to the "academic achievement perception" variable. the difference between the group averages was found to be significant. As a result of the analyzes, it was determined that in the case of the "academic achievement perception" of the participants, the difference between the groups that marked the "successful" and the "intermediate level successful" options was realized to be in favour of the group of students who see themselves "successful". Consequently, it can be argued that the "perception of academic achievement" has a significant effect on the attitudes of pre-service teachers towards the course. 
In line with the results of the research and related literature, in order to improve the interest and attitudes of the music teacher candidates to the course in a positive way, firstly the related department lecturers, then the department chairmanship work in cooperation. In order to provide this course with more efficient, high-quality and modern methods, the content and objectives of these courses should be re-organized and programmed according to the curriculum of primary and secondary school syllabi in the ideal music teacher model and the weekly course hours and credits of the piano lessons should be increased. It can also be suggested that scientific researches on the subject can be carried out experimentally with larger sample groups.

Furthermore, in addition to the ability to play the piano, which is necessary in the music teaching profession, the transfer of knowledge between the other courses should be given to the teacher candidates more carefully and selectively.

In addition, the attitude scale towards the piano lesson, can determine whether the piano syllabus present in the education process shows the desired success and whether the expected attitudes are developed. Measuring the attitudes towards the piano lesson and the continuous monitoring of the education and training process makes it possible to take required measures to identify and solve the problems that may arise at each stage. The information obtained from the attitude scale can be used by the teachers and can help students to evaluate themselves and to set personal goals (Tufan and Güdek, 2008: 86). Therefore, it is recommended to develop new scales with different objectives, related to instrument training, for testing the efficiency of the field.

In the present study, the factors that question the attitudes of the $4^{\text {th }}$ grade students studying in the Music Education Department of the Faculty of Education were investigated. Further research can be carried out with pre-service teachers studying in different Education Faculties in Turkey.

\section{References}

Bakığlu, Ç. (2012). Comparison of Music Teaching Program Students and State Conservatory Music Students' Attitudes Towards the Piano, Yayımlanmamış Yüksek Lisans Tezi, Karadeniz Teknik Üniversitesi Eğitim Bilimleri Enstitüsü.

Bakioğlu, Ç., \& Kurtuldu, K. (2015). A study of Attitude Scale Development for Piano Course, Alan Eğitimi Araştırmaları Dergisi (ALEG), 1(1), 33-39.

Canakay, E. U. (2006). Development of Attitude Scale on Music Theory Course, Ulusal Müzik Eğitimi Sempozyumu Bildiri Kitabı, 26-28 Nisan, Pamukkale Üniversitesi Eğitim Fakültesi, Denizli.

Emir, S. (2001). The Effect of Creative Thinking on Retention in Social Studies Teaching, Yayınlanmamış Doktora Tezi, Hacettepe Üniversitesi, Sosyal Bilimler Enstitüsü, Ankara.

Ercan, N. (2008). Principles and Methods in Piano Education, Ankara: Sözkesen.

Gasımova, T. (2010). Techniques in Teaching and Learning Piano, Atatürk Üniversitesi Güzel Sanatlar Enstitüsü Dergisi, 25, 99-106.

Gömleksiz, M. N. (2003). Validity and Reliability of an Attitude Scale in English Affective Area, Firat Üniversitesi Sosyal Bilimler Dergisi, 13(1), 215- 226.

Güdek, B. (2007). An Investigation on the Attitudes of 1st and 4th Grade Students of Music Education Department in Terms of Different Variables.

Gün, E., \& Köse, H. S. (2013). Attitudes of Music Education Students Towards Piano Course, Turkish Studies, 8(3), 247-261, Yayınlanmamış Doktora Tezi, Gazi Üniversitesi Eğitim Bilimleri Enstitüsü.

İnceoğlu, M. (1993). Attitude, Perception, Communication, Ankara: Verso Yayınc1lık.

Kasap, B. T. (2004). A Research on Piano Courses in Music Education Departments, 1924-2004 Musiki Muallim Mektebinden Günümüze Müzik Öğretmeni Yetiştirme Sempozyumu. Isparta: Süleyman Demirel Üniversitesi.

Kasap, B. T. (2005). The Importance Of Functional Piano Skills For Music Teachers. Gazi Üniversitesi Gazi Eğitim Fakültesi Dergisi, 25(1), 149-154.

Kıvrak, İ. (2003). Piano Education in Music Teacher Training, Cumhuriyetimizin 80. yllında Müzik Sempozyumu (s. 209-211). Malatya: İnönü Üniversitesi.

Küpana, M. N. (2011). Testing the Effectiveness of the Piano Deciphered Teaching Program for Music Teacher Candidates, Marmara Üniversitesi Eğitim Bilimleri Enstitüsü, Doktora Tezi.

Macmillan, J. (2004). Learning the piano: a study of attitudes to parental involvement. British Journal of Music Education. 21(3), 295-311. https://doi.org/10.1017/S0265051704005807 
Morgan, C. T. (1995). Introduction to Psychology, Çev. Sirel Karakaş. Ankara: Meteksan A.ŞÖzen, M. (1998). Gazi University Education Faculty Music Education Department's Final Grade Students' Skills in Using the Piano According to the Requirements of Music Education, Yayımlanmamış Doktora Tezi. Ankara: Gazi Üniversitesi Fen Bilimleri Enstitüsü.

Otacıoğlu, S. G. (2005). A Model Experiment for Music Teaching Piano Education Course, Doktora tezi, Marmara Üniversitesi Eğitim Bilimleri Enstitüsü.

Özmenteş, S., \& Özmenteş, G. (2009). Attitudes Toward Instrument Study, Individual Characteristics and Performance Level Relationships. Kastamonu Ĕ̈itim Dergisi, 17(1), 353-360.

Tufan, E., \& Güdek, B. (2008). Development of an Attitude Scale for Piano Lessons, GÜ, Gazi Eğitim Fakültesi Dergisi, 28(1), 75-90.

Ülgen, G. (1995). Educational Psychology: Concepts, Principles, Methods, Institutions and Applications, Ankara: Bilim Yayınları.

\section{Copyrights}

Copyright for this article is retained by the author(s), with first publication rights granted to the journal.

This is an open-access article distributed under the terms and conditions of the Creative Commons Attribution license which permits unrestricted use, distribution, and reproduction in any medium, provided the original work is properly cited. 